6. Nein vs. Nicht // Youtube. URL: https://www.youtube.com/watch?v= vC_7XBaqse4

7. Showing our house // Youtube. URL: https://www.youtube.com/ watch? $\mathrm{v}=$ McbEFTuRIZo

8. What Germans have for Breakfast // Youtube. URL: https://www.youtube.com/watch?v=kwdnxwQCoXM)

9. Zakharova M. V. Opyt orhanizatsii samostoiatelnoi raboty po audirovaniiu $\mathrm{v}$ obuchenii anhliiskomu yazyku studentov-bakalavrov (na primere 23.03.01 Tekhnolohiia transportnykh protsessov). Internet-zhurnal «Mir nauki», 4. 2018. URL: https://mir-nauki.com/PDF/72PDMN418.pdf

10. Zarutskaia E. V. Podkasty ynternet-resursa All Ears English v obuchenyy ynteraktyvnoi storone ustnoho obshchenyia na anhlyiskom yazbke studentov urovnia B2-C1. Pedahohyka. Voprosy teoryy y praktyky, 4(1). 2019. C. 25-28. URL: https://doi.org/10.30853/pedagogy.2019.1.5

DOI https://doi.org/10.30525/978-9934-588-90-7-80

\title{
«A TRUE STORY ABOUT A ВLACК САT/ ПРАВДИВА ІСТОРІЯ ПРО ЧОРНУ КІШКУ» МАТЕРІАЛИ ДО БІНАРНОГО УРОКУ ЗАРУБІЖНОЇ ЛІТЕРАТУРИ ТА АНГЛІЙСЬКОЇ МОВИ
}

Гольтцш В. Ю.

викладач англійської та німецької мови циклової комісії украӥнської та англійської філології

Жукова О. В.

викладач зарубіжної літератури

та культурології ииклової комісії суспільних дисциплін

Бериславський фаховий педагогічний коледж імені В. Ф. Беньковського

Херсонського державного університету

м. Берислав, Херсонська область, Украӥна

Згідно з освітньою реформою, однією з ключових компетентностей $\epsilon$ володіння іноземною мовою як незамінним засобом комунікації для фахівців усіх ланок суспільства. Окрім того, на засадах гуманістичної спрямованості системи освіти України перед закладами фахової освіти як однією із задач стоїть створення оптимальних умов для розвитку пізнавального потенціалу фахівця, який повинен мати глибокі загальні та професійні знання, володіти спеціальними професійними навичками та вміннями. Саме тому так важливо на уроках зарубіжної літератури та 296 
іноземної мови виховувати вміння прислухатися до думки інших, формувати комунікативні навички, мовні компетентності у студентів фахових навчальних закладів. Сучасні викладачі, розуміючи покладену на них відповідальність, синтезують різні методи та педагогічні технології, інтегрують матеріал навчальних дисциплін, шукаючи нові можливості підвищити ефективність навчання кожного студента. В свою чергу сучасні заняття 3 мови та літератури спрямовані на засвоєння не тільки лексичного та граматичного матеріалів, але й фактів про відомі твори. Це передусім інтерпретація тексту, діалог культур, розвиток логічного мислення студента та формування його моральних якостей.

Наведені матеріали по темі «А True Story about a Black Cat/ Правдива історія про Чорну кішку» рекомендуємо використовувати в процесі інтеграції зарубіжної літератури та англійської мови у вигляді бінарного уроку.

1. При підготовціi до сприйняття іншомовного мовлення пропонуємо створити інтригу спільного пошуку теми заняття із змісту загадок про Чорну кішку.

2. Для мотивачї навчальної діяльності, згадуючи ключові поняття «літератури жахів», окреслюємо історичні місця і постаті. Радимо використати вправу «Знайди відповідності» (студенти по черзі перегортають аркуші зі словами за темою на англійській мові та визначають відповідний переклад українською).

3. Актуалізація опорних знань вимагає пригадати літературних представників жанру хоррор із вивченого за заняттях зарубіжної літератури, а під час вправи «Асоціативний кущ» студенти висловлюють ідеї, формуючи асоціативний кущ з поняттями та фразами за темою заняття - про чорного кота.

4. Для фонетичної розминки із капелюху чорного кольору студенти дістають аркуші зі скоромовками та промовляють їх, звертаючи увагу на правильну вимову.

5. На етапі подання лексичного матеріалу вдалою вважаємо вправу «Пінг-понг» (Пропедевтичне завдання: студент читає вислів відомих людей про чорних котів, який знайшов вдома, а інший студент, кому припав в руки м'яч, перекладає почуте рідною та/або іноземною мовою).

6. Вдосконалення мовленнєвих вмінь та навичок організуйте, використовуючи завдання для тренування аудіювання та письма, зверніться до фрагменту із новели Е.А. По «Чорна кішка». Цікаво про незвичайне: студенти подають підготований заздалегідь матеріал - факти та забобони жителів різних країн про чорну кішку. Крім цього, з метою перевірки сформованості граматичних навичок, викладач просить студентів пояснити вживання артиклів в конкретному реченні, яке прозвучало в повідомленні.

7. Для підбиття підсумків та рефлексї пропонуємо використати метод «Чарівних капелюхів» та невелику бесіду. Спираючись на 
власний досвід студентів, доходимо до висновків, що навіть маленьке порушення правил не допустиме в житті людини, тому що це інколи приводить до невиправних наслідків .

8. Домашнє завдання: Студенти складають особисту (кумедну або не надто веселу) історію обсягом $15-20$ речень, пов'язану з чорною кішкою. Як альтернативу, пропонуємо переглянути мультиплікаційний фільм https://www.youtube.com/watch?v=90_eYJjPNOw або ось таку історію https://www.youtube.com/watch? $\mathrm{v}=$ IhjrtGdtaxI i переказати побачене.

Критерієм доцільності проведення бінарних занять $є$ їхня ефективність: вони дозволяють за менший термін навчання засвоїти більше інформації, сприяють прискоренню оволодіння програмовим матеріалом, що в свою чергу вивільняє додатковий час на закріплення та практичне застосування компетентностей.

\section{Література:}

1. Easy stories in English URL: https://easystoriesinenglish.com/cat/

2. Як це - сучасно викладати іноземні мови URL: https://nus.org.ua/ view/yak-tse-suchasno-vykladaty-inozemni-movy/

3. Black Cat Riddles For Kids URL:https://riddles-for-kids.org/black-catriddles/

4. The black cat - second part worksheet URL: https://www.liveworksheets.com/qr1003116ze

5. Black cats. The myth, the legend and the science URL: https://www.petplace.com/article/cats/pet-behavior-training/black-cats-themyth-the-legend-and-the-science/

6. Kid-E-Cats The Day Of The Black Cat - Episode 41 URL: https://www.youtube.com/watch?v=90_eYJjPNOw

7. Poe E. The Black Cat and Other Stories / E. Poe. CRW Publishing Limited, 2015. $-190 \mathrm{c}$.

8. Журнал «На Урок» Інтегровані уроки: від теорії до практики https://naurok.com.ua/post/integrovani-uroki-vid-teori-do-praktiki

9. Зарубіжні письменники. Енциклопедичний довідник. / за ред. Н. Михальської та Б. Щавурської. Тернопіль: Богдан. Том. 2. Л-Я C. $359-361$.

10. Савоськина Татьяна та Давид Анастасия. Поетика містичних новел Едгара Аллана По/Наука онлайн: Міжнародний електронний науковий журнал 2019. № 12.

11. Тітаренко Л.М. Євроінтеграція у вивченні літератури в школі. Зарубіжна література в школі. 2017. № 17/8. С. 4-6.

12. Ткаченко I. А. Впровадження бінарних уроків у навчальний процес. Інформатика в школі. 2015. № 3 (75). С. 2-3. 